\title{
Aficionados, Academics, and Danzón Expertise: Exploring Hierarchies in Popular Music Knowledge Production
}

Back in 1949, in his article "Professionalism and Amateurism in the Study of Folk Music," Charles Seeger outlined three distinctions commonly made between professional and amateur folk music researchers in the USA. First, that the professionals' field provides their livelihood, while amateurs are hobbyists. Second, professionals are disciplined, while amateurs are not. And third, drawing from the Latin etymology amare, amateurs "love" their field, while such love would endanger professionals" “objectivity” (1949:107). Seeger went on to critique the assumptions about discipline and love. He argued that discipline is not determined by training, experience or livelihood, and that many professionals love their field, particularly humanists and social scientists, while some amateurs do not. Seeger considered a balance between love of a field and a love of study as ideal for professionals. He concluded that, "with the prejudices and resistances bred into a professional musicologist by years of training in and association with fine-art music, it is not to be wondered at if some comparatively untrained amateur can get at the insides of a folk music situation better than he [sic]" (1949:112). Seeger's conclusion related both to performance, and to knowledge about musics more generally. Relationships between amateur and professional performers, academics, knowledge, and power have elsewhere and since received substantial critical attention more broadly in ethnomusicology (e.g., Hood 1960; Barz and Cooley 1997). Ways of knowing, and how these are created, valued and negotiated has also been explored by amongst others, ethnographers from the USA (Basso 1996), Brazil (Viveiros de Castro 1998) and the Netherlands (Mol 2003). However, amateur music scholars have been somewhat sidelined. My concern in this paper is with amateur scholars of Cuban popular music in Mexico, and with their relationships to broader contexts of knowledge production. 
As Seeger intimated, amateur researchers have often been established as "other" to the esteemed rationality of the academy, despite overlaps and blurred boundaries between professional and amateur researchers. Amateur researchers include (but are not restricted to) intellectuals, fans, and aficionados. Intellectuals, both within and beyond the academy, have received substantial critical attention (e.g., Camp, et al. 1991, regarding intellectuals and power in Mexico; and Kurzman and Owens 2002, on the sociology of intellectuals in Europe and the USA). In the USA and UK, fans have been the subject of many studies, particularly fans of Anglophone popular culture (e.g., essays in Lewis 1992). Hills (2002:xvii) distinguishes between 'scholar-fans' inside the (UK and US) academy, who have attracted academic consideration, and 'fan-scholars' outside the academy, more akin to aficionados, who have largely been ignored (Faulk's archival research on English, music-hall aficionado Arthur Symons, 2000, being an exception). Understandings of aficionados, fans, and intellectuals overlap, as do amateur experts and audiences more broadly, yet distinct spaces have been carved for each.

In this paper, I use the term "aficionados" to denote non-professional or amateur hobbyists who possess remarkable specialist knowledge, and often display affective sentiment for a subject or activity. Aficionados might be distinguished from fans, who are devotees of particular people or things, such as stars, sports clubs and television shows, rather than hobbyists. The English word "fan" has its roots in notions of religious fanaticism, and Anglophone literature on fandom has persistently criticized pejorative notions of fans as emotional, as excessive, subjective and irrational (e.g., Grossberg 1992). Akin to amateurs and fans, aficionados have been allied to sentiment. Etymologically, aficionado, the Spanish for amateur practitioner, derives from the Latin affectio, to affect or influence (the English word "aficionado" comes from the Spanish). A relational, affective link is implied between the aficionado and their knowledge: the aficionado is both affected by and affects their subject. There is scope for further 
research on amateur scholars in relation to the "affective turn" (Pedwell and Whitehead 2012), but I focus here on amateurs' relationships to hierarchies of knowledge production.

The sentiment engendered in amateur scholars' subject of study or activity has often been juxtaposed with the seriousness of "legitimate" academic research, and much literature on fandom has been concerned with critiquing such juxtapositions (e.g., Grossberg 1992; Jenson 1992). Relationships between rationality, sentiment, objectivity, discipline (or rigor), and institutional legitimation have continued to pervade this scholarship on fans (e.g., Hills 2002) and also, to a lesser extent, aficionados (Faulk 2000). Jensen (1992) has pointed to an us-them dichotomy which pervades US journalism and earlier literature on fandom, whereby fans are depicted as obsessed loners, hysterical crowd members, or deviant outsiders, in contrast to elite, respectable, rational academics. She positions aficionados as academics, rather than as amateur researchers, building on the idea, which she critiques, that aficionados focus on more elite objects of study. Where class-based notions of taste have been applied, aficionados are often ascribed more gravitas than fans. They have been located in a position between fans and academics (for example by Faulk 2000). A similar space has also been constructed for intellectuals, where they are deemed more rational than fans. However, curiously, as Williams elucidates, although the term "intellectual" refers to mental apprehension, in early nineteenth-century Europe it acquired negative connotations of theoretical abstraction which was contrasted with evidence-based reason (1983:170). Thus, although there are distinct registers of intensity at play here, and historical and geographical contexts must be taken into account, amateur scholars (aficionados, fans, and intellectuals) have often shared an ambivalent relationship to rationality, and concomitantly to political and academic institutions.

In the early twenty-first century, hierarchies of knowledge production persist. Affective knowledge is ranked lower than purportedly objective 
knowledge. These hierarchies remain largely institutionally and culturally entrenched, within for example the US academy, despite several decades of anthropological, ethnomusicological, feminist and postcolonial critiques of both notions of truth and objective knowledge (e.g., Clifford 1986; Haraway 1988; Harding 1996; Stewart 1996; Barz and Cooley 1997). Similar hegemonic dynamics are evident elsewhere (see, for example, the critique by Santamaría Delgado 2007, of the epistemological base of Latin American music schools). Although amateur scholars are often key sources for academics, their purported passion for their subject and amateur status have meant that they still rarely gain the recognition they deserve. The epistemic worth of their activities is still largely undervalued, and amateur experts continue to be excluded from the status, prestige and economic benefits of the academy.

In this article, I draw from ethnographic material to consider how amateur researchers negotiate social contexts where they are often marginalized. I focus on the mostly older men who identify as danzón aficionado investigators in Mexico (henceforth aficionados) through the experiences of two key actors: Ciro Carlos Mizuno Guzmán and Jesús Flores y Escalante. Danzón is a popular Cuban musicdance form performed daily in Mexico City and the Port of Veracruz, Mexico. When I asked musicians and dancers about danzón, many told me that they knew very little, since the kind of knowledge they thought I wanted, and would need in order to write about danzón, was the huge swathes of "truths" that experts including aficionados - expound. Amateur scholars, with encyclopedic knowledge of the genre, actively participate in transmitting understandings of danzón. I introduce these Mexican danzón aficionados in the next section of the article, setting out a typology of danzón expertise, exploring how these aficionados acquire and transmit their knowledge, and probing the workings of notions of truth and ignorance. I then examine ways in which danzón aficionados enact their expertise and, drawing on Bourdieu (1993), how they employ a form of masculine symbolic capital in their struggles for positions in this field of 
expertise. In the final sections, I analyze danzón aficionados' relationships with musicians and dancers, and power dynamics between these aficionados and academics. I conclude with a consideration of aficionados and secondary literature on relationships between hegemonic and regional scholarships, to reflect on hierarchies of knowledge production more broadly.

\section{Danzón Aficionados and their Knowledge}

So who are danzón aficionados and what kind of knowledge do they have? Let me begin by introducing danzón aficionado Ciro Carlos Mizuno Guzmán (henceforth Mizuno), born in 1942 in Túxpam, Veracruz. From a young age, Mizuno loved Cuban music and dance, and especially Cuban son. For most of his working life, he was a special policeman and, for leisure, regularly frequented Mexico City's dancehalls and cabarets. He built up an encyclopedic knowledge of Cuban music by reading books, conducting interviews, and travelling to Cuba. In 1975, with a group of friends, he set up the National Association of Public Speaking about Cuban Son, ANASONTRI (Asociación Nacional de Soneros de Tribuna A.C.), to investigate Afro-Antillean music in Mexico, particularly Cuban son, and to disseminate their findings. They did this via radio broadcasts, a newsletter, and talks and conferences in cultural institutes, Rotary Clubs, and government organizations. "We do it for the love of the art," he told me, "we do not have obligations [compromisos] to anyone. We [ANASONTRI] do not belong to any political party, sect, religion, and we certainly do not aim to make a profit. [...] The sole aim of everything we do is that it be useful to people interested in the subject, be it son or danzón" (interview, 21 April 2007, Port of Veracruz). ${ }^{1}$ ANASONTRI also gave certificates of recognition (reconocimientos) to musicians, thereby bestowing and gaining respect from these musicians. But, after the 1985 earthquake, Mizuno moved out of Mexico City, as did other members of ANASONTRI. Mizuno spent several years in the Port of Veracruz. There he gave talks about Cuban son, but as interest in danzón grew, he was increasingly asked 
to lecture on danzón (having been an aficionado for several decades), a subject he has now been giving talks about for over 25 years.

Danzón emerged in Cuba in the late nineteenth century and was popular throughout Mexico until the mid-twentieth century. Its popularity waned slightly in the 1960s and 1970s, and from the 1980s people talked about "rescuing" danzón, formalizing its transmission and choreography, and ritualizing its performance in spectacles. Demand for talks rose during the late 1980s and 1990s, as a form of danzón revival spread throughout urban Mexico, attracting thousands of new 50-plus-year-old dancers, and some younger people (see Malcomson 2012). This revival was primarily spurred by the formation of dance groups, the decentralization of Mexican cultural institutions, and María Novaro’s acclaimed and widely-disseminated film, Danzón (1991). Although danzón had been overshadowed by tropes of Mexican nationalism before the 1980s (Malcomson 2010a), it was then that it became more explicitly entangled with the cultural nationalism that had transformed many regional "folkloric" music-dance forms earlier in the century. As Turino (2003) explores, regional Mexican folkloric music-dance forms were performed in schools, on stages and in the media, forming a canon over time where each regional form came to index the nation. From the 1980s, danzón dancing became entwined with similar folkloric logics and increasingly conformed to what Turino describes as "dominant, typically 'modern' cosmopolitan, aesthetics and contexts" (2003:185). Danzón steps became more stylized and, akin to folkloric ballets such as Amalia Hernández's Ballet Folklórico de México, more "modern" and "ballet-like," with groups of dancers wearing matching outfits ("uniforms") and performing entire pieces in chorus-like unisons. More middle-class danzón dancers began to join the mostly lower-middle class performers and, since the 1980s, thousands have joined the dance. Often with the support of local cultural institutes, dozens of new danzón dance groups formed, each incorporating bureaucratic hierarchies with presidents, treasurers and secretaries. Dancers from these groups (as well as a few others) 
began to travel to danzón festivals throughout Mexico. Many of these danzón festivals included "national" demonstrations where dance groups began to represent their states and locales with choreographic displays, reproducing cultural nationalist logics. These festivals were often (partly) staged and sponsored by municipal governments and state cultural institutions (such as CONACULTA, the National Council for Culture and the Arts) keen to promote local consumption and regional development (Piedras Feria 2006, provides an analysis of economic development based on Mexico's culture industries). However, some dancers, particularly in Mexico City and the Port of Veracruz, opted not to join groups and continued to perform in the older dance style (see Malcomson 2010b). The music did not change as much as the dance, and mostly male, lower-class musicians continued to perform danzón. Since the 1950s, the danzón music repertoire has changed little, but particular pieces have become more canonic. ${ }^{2}$ This is due, in part, to dance groups repeatedly requesting particular tracks for their dance spectacles, and also partly because danzonera (danzón ensemble) directors are less often composers in the twenty-first century as they were in the 1950s. ${ }^{3}$ Musical aesthetics from the mid-twentieth century have also largely been maintained (with the influence that mambo had on such ensembles as Carlos Campos y su Orquesta rarely being perpetuated). Akin to the Nicaraguan baile de marimba examined by Scruggs (1998) where the dance underwent similar transformations, higher social classes were attracted to performing the new-fangled dance, but not the music.

Cultural institutes, and their festivals, played a vital role not only in promoting danzón as a music-dance form, but also in propagating knowledge about danzón. Often coordinated by influential dance group leaders and sponsored by state organizations, danzón festivals commonly include daytime conferences, workshops, dance competitions, and dance group displays, and culminate in evening dance events with well-known danzón ensembles performing. The conference element of these festivals includes lectures, round-table discussions or 
workshops, and speakers are usually aficionados, academics, and musicians, who frequently share a platform in this context. These conferences are often hosted in local cultural centers and legitimate these festivals by providing academic gravity. Thus, the revived danzón provided a space for aficionados to emerge as public speakers, particularly at these danzón festivals. Danzón performance, and knowledge about it, began to be incorporated into the cultural productions (including music, dance, art, history, literature) which continue to play an important role in ongoing nation-building processes in Mexico. Although public intellectuals had made vital contributions to these processes, they have not been concerned with danzón (with the exception of Carlos Monsiváis' two short essays on Mexico City's dancehalls, 1981). With the danzón revival, some danzón aficionados now gained considerable state support, both for travelling to speak at events, and by being ordained "chroniclers" of cities.

In order to make sense of knowledge production processes, I distinguish between three types of danzón expert, aware that these categories overlap: aficionados, academics, and masters of ceremonies. The first two types are investigators who base their material on primary research, including interviews, archival work, and personal experience. I explore power dynamics between hegemonic and regional scholarships further below, but pertinent here is that generally academics have more educational status than aficionados, institutional support, an income, and adhere more strictly to academic conventions. In terms of source material and output, aficionados often overlap with academics in terms of production values, circulation, and consumption. Some aficionados gain part of their income from their expertise, but most do not. Moreover, some pride themselves on "not charging for culture," and working on an expenses-only basis.

Danzón is distinct from the spheres of (US and UK) fandom analyzed by Fiske (1992) where culture industries cater to fans' desire to accumulate knowledge by creating vast amounts of material in newspapers, magazines and other media about "the object of fandom [...][such as] gossipy speculations about 
the private lives of stars" (1992:42). First, although some Mexican danzón aficionados do focus on famous danzón performers, particularly Cuban musicians, there are arguably few danzón stars. And second, there is not a consolidated culture industry producing knowledge about danzón. Instead, danzón aficionados play a key role in creating, reproducing and disseminating knowledge about danzón. In Gramscian terms, they are the "organic intellectuals" (2011:202) of Mexico's danzón "world," since they emanate from this world, and both create and are principal disseminators of hegemonic ideas about danzón.

The third type of danzón expert are the masters of ceremonies who largely collate and reproduce the work of academics and aficionados, complementing it with their own, mostly recent, personal experience, and generally being less critical than other investigators. Masters of ceremonies often learn verbatim their accumulated knowledge enabling them to recite it in public, notably at danzón events and on radio shows. While masters of ceremonies gain prestige and satisfaction from public-speaking, they rarely critique other experts or claim personal expert authority. In the Port of Veracruz, masters of ceremonies not only introduce danzón events, but commonly speak between danzón tracks about the history of danzón, and the history of the Port. They (re)create histories for their audiences which include musicians, dancers, local onlookers, and national and foreign tourists.

Let us turn now to the subject of aficionados' expertise, which primarily consists of historical information about danzón and generic shifts. Music and musicians are the prime focus, with the dance often given lesser consideration. Danzón aficionado Carlos Mizuno introduced above, for example, divides his lectures into four parts which translate as: "the historical antecedents of danzón, the most widely-disseminated history, the most widely-disseminated myths, and the seldomly-disseminated truths." Such divisions point to moral-laden notions of first, histories, second, truths, and third, myths. These elements correspond to the 
main areas of interest among Mexico’s danzón aficionados, and I will use this structure to explicate aficionados' expertise.

First, in terms of histories, the pivotal event in the history of danzón, according to aficionados, musicians and dancers alike, is its beginning. Most concur that the first "official" performance of a danzón occurred on the $1^{\text {st }}$ of January 1879 in Matanzas, Cuba with Miguel Faílde Pérez's Las Alturas de Simpson (Simpson Heights). This event, together with "the historical antecedents of danzón" (including English country dances, Franco-Haitian contredanses, and Cuban contradanzas), and the subsequent danzonete, mambo and cha-cha-chá, have been documented by Cuban investigators (Malcomson 2011, provides an analysis of this history). While several Mexican aficionados have travelled to Cuba, the authority of a number of Cuban texts remains largely uncontested, such as works by Carpentier (1946), Galán (1983) and León (1984). Although these Cuban authors do not always agree, their material is sufficiently consistent to form the basis of a standard history of danzón, at least in terms of its accepted "historical antecedents" and "most widely-disseminated history." The majority of Mexican danzón aficionados do not read English and are unlikely to engage with the little material there is on danzón that is not in Spanish.

Second, in terms of truths, Mexican danzón aficionados treat these Cuban texts as sacrosanct and rarely criticize them. Yet the details of these same canonic texts also provide the primary source material for the "seldomly-disseminated truths," the anomalies that these aficionados use to distinguish between levels of expertise. For example, aficionado Carlos Mizuno argues, following Carpentier (1946), that contrary to popular opinion, Miguel Faílde Pérez did not create the first danzón and instead this honor should be bestowed to Manuel Saumell Robredo (1817-1870) who included the cinquillo pattern... , characteristic of danzón, in some of his contradanzas (see Malcomson 2011:267). What is noteworthy here, is that the temporal and spatial distance of Mexican aficionados 
from the Cuban sources so crucial to histories of danzón contributes to their dependence on these canonic Cuban texts.

Third, in terms of myths, aficionados' notions of the "most widelydisseminated myths" about danzón usually concern 1940s and 1950s Mexico. They often relate to Mexico City's legendary dancehalls, especially the Salón México, to the zoot-suit-clad pachucos, and to couples dancing danzón on a brick or a crate of beer. Many of these myths are infused with ideas about class and morality, and provoke strong reactions, as I discuss below. They are frequently referred to in the books created by Mexican danzón aficionados (such as Flores y Escalante 1993) and journalist Ángel Trejo (1992) which primarily focus on histories of danzón in Mexico City and the Port of Veracruz, and are often based on personal experience. There is a hierarchy in terms of the types of personal experience valued in the creation of danzón knowledge. Regular participation in the dancehalls and cabarets of Mexico City, and to a lesser extent the Port of Veracruz, especially before the 1950s, is most highly valued. More recent experience of danzón, particularly in the last 25 years is valued less, as it is shared by contemporary aficionados, as well as new and seasoned performers. Being a primary source of material that is not contestable by others protects older experts, such as Francisco Rivera Ávila "Paco Píldora" (1908-1994), who both witnessed and shaped histories of Veracruz's danzón, and provided primary material for historians García de León Griego (1996) and García Díaz (2002), and danzón aficionados such as Jesús Flores y Escalante (1993). Meanwhile, younger danzón aficionados (born since 1940) often criticize each other's work, treating it as both a resource and a target, resonating with academic practice. This is partly because younger aficionados' knowledge is generally based on more contestable living memory and personal experience, but also because they compete with each other in this sphere of expertise.

\section{Creating Truth and Ignorance}


Having explored the kind of knowledge danzón aficionados have, let us consider how they relate to each other, to other experts, and to their audiences. Notions of truth, reason, and facts are key to understanding both aficionados' raison d'être and the field in which operate, for they are used to both educate and to undermine. Danzón aficionado Carlos Mizuno is keen to refute fallacies and intent on discovering, delivering and protecting "the truth." He argues that he stands up and speaks "so that people are not confused by the rubbish others say, so that people know what they are doing, so they become less ignorant" (interview, 21 April 2007, Port of Veracruz). Like many aficionados, he often draws on myriad facts to "correct" the truths of other aficionados, as well as academics, at public talks and conferences. Another technique which aficionados use might be exemplified by an encounter Mizuno described to me when he attended a talk by danzón aficionado, Jesús Flores y Escalante:

I went [to a conference] because I was interested. They started saying a load of rubbish and after five minutes I realized that they didn't know what they were talking about. So I asked "Do you know what danzón is?" “No, I’m not interested” [the speaker, Jesús Flores y Escalante replied]. "But you've written a book called Documentary and Graphic History of Danzón in Mexico?” [(1993)][...] I don’t insult anyone, I just say things as they are, not as I want them to be. [...] I tell people I like: "I didn't come here to annoy anyone. What I want is that people realize that you are fooling them. [...] When you go to a cultural forum and they start saying a load of rubbish, most people stay quiet, but I don't, I stand up [...] It's not that Carlos Mizuno says it, or wants to impose, but just that it's the result of an aficionado investigator of more than 48 years (interview, 21 April 2007, Port of Veracruz).

In this example, Mizuno accused Flores y Escalante of saying a load of rubbish in a setting legitimated by being a cultural forum. Mizuno claimed to be compelled to correct Flores y Escalante, to ensure that other people were not misled. 
However, rather than picking up on an "incorrect" fact (often a "seldomlydisseminated truth"), Mizuno uses a distinct tactic in challenging his fellow aficionado. In this instance he asked Flores y Escalante one of his stock questions: “Do you know what danzón is?” Flores y Escalante, who knew Mizuno’s tactics well, was not interested in engaging with Mizuno's challenge and chose not to reply. However, like other aficionados, Mizuno creates yardsticks of knowledge which he thinks experts and dancers alike should have, and he is very clear-cut about the definition of danzón he considers correct: "danzón is a danceable genre [...] It consists of six parts [calculated to include the repetitions of the A section of the rondo form, ABACAD, that danzón commonly takes]. It is danced with the basic step of danzón, the caja [box]" (interview, 21 April 2007, Port of Veracruz). While other people may have distinct definitions of danzón, Mizuno asks a specific question to which he expects a specific answer, or something closely related.

Mizuno often told me he wanted to educate people and ensure that they were not ignorant. Yet in so doing, he simultaneously demarcates boundaries of expertise and establishes his own expertise. The effect of this, maybe unintentionally, is that he sets up the possibility of creating ignorance in others, by constructing a hierarchy of knowledge. This process resonates with Hobart's (1993) work on knowledge claims and attributions of ignorance in development projects. Hobart argues that "as systematic knowledge grows, so does the possibility of ignorance" (1993:1). Like other knowledge-disseminators, Mizuno creates hierarchical benchmarks of knowledge and simultaneously the probability of ignorance. However, "ignorance” was a word Mizuno used frequently, mostly as a form of disparagement.

In Mexico, as elsewhere, the notion of ignorance has class connotations relating to a lack of education, as well as a lack of interest. The creation and ascription of ignorance in the danzón context can also be understood as a gendered act in this predominantly homosocial sphere, as male aficionados mainly 
critiqued and ascribed ignorance to other men. Not only do women rarely figure as protagonists in histories or contemporary discussions of danzón, despite their presence (as composers such as Coralia López, and essentially, in this heteronormative dance, as dancers), but women were sometimes dismissed prior to becoming worthy of the descriptor "ignorant" (ignorante). Public performances of masculinity were particularly important in some aficionados' struggles for status, as we shall see. More humble statements were often reserved for more private settings. For example, returning to the above encounter, there were times when Mizuno discussed Flores y Escalante's work with humility, saying that Flores y Escalante was an investigator, while Mizuno was merely an aficionado, as although Mizuno has interviewed hundreds of musicians, dancers and other experts, Flores y Escalante has conducted archival research in the Yucatán.

But Jesús Flores y Escalante had a slightly different perspective. Born in 1944 in the city of Puebla, he was a voracious reader from a young age. At 14, he began working on radio shows, mostly relating to rock music. He studied painting before entering army school, where he played the bugle in the military band. He then moved to Mexico City, finished secondary school and worked in mountain rescue, before getting married. For decades he hosted, produced, and directed radio shows, including El Rinconcito del Danzón (The Little Corner of Danzón), and he ran the radio station, XEB, La B Grande de México (the B of Mexico), until he died, aged 68, in 2012. When I interviewed him, Flores y Escalante, like other aficionados, stressed the important potential of radio shows for educating people about danzón. He also claimed superiority over other danzón experts, including Mizuno. Flores y Escalante supported this claim with reference to his years in radio; to having set up the Mexican Association of Phonographic Studies, AMEF (Asociación Mexicana de Estudios Fonográficos), in 1985, which he told me holds an archive of more than a million recordings; to writing two books on danzón (1993; 1994b); producing several CDs of historical recordings (e.g.,1994; 2001); being named a "Chronicler of Mexico City;" and conducting archival 
research. These achievements distinguish him from other Mexican danzón aficionados, particularly due to the esteem gained from writing books and conducting primary historical research. Flores y Escalante also suggested he was passionate about popular culture generally, rather than music specifically. In addition to books on popular music, he has written on food (1994a) and a dictionary of Mexican slang (1994c).

As we have seen, aficionados compete to impose their version of events, to gain legitimacy, and to establish their authority. Flores y Escalante declared, with reference to himself and his colleague, the medical doctor Pablo Dueñas (born 1959, and author of several books on bolero, e.g., 1993): "We are not modest!" (interview, 15 June 2007, Mexico City). Being immodest demarcates and legitimates experts as truth-bearers, as well as protecting them from potential attacks. As in academia, there are also sometimes allegations of theft and unoriginality amongst Mexican danzón aficionados. Flores y Escalante, for example, accuses everyone of stealing from him. He told me: "all the danzón research until now is scissor and paste. I haven't seen anything new. The words they say that $[\ldots]$ talk about danzón having certain characteristics are all taken from my book. There is so much that can be said about danzón, but they don't sense it" (interview, 15 June 2007, Mexico City). I responded by asking him about anthropologist Amparo Sevilla's (2003) excellent ethnography of Mexico City's dancehalls, Los Templos del Buen Bailar (The Temples of Good Dancing). "I don't know it," he replied. "Amparo Sevilla is a friend of ours, we're very fond of her. I don't know if she's published a book or not. It's probably based on mine!" While Amparo Sevilla's being a woman may have played into this dismissal, and there are books that are very similar to Flores y Escalante's, there is an underlying arrogance that his is the work that everyone copies. He implies that he is Mexico's only original danzón investigator, the only original "truthbearer." While danzón aficionados like Flores y Escalante and Mizuno operate in the same sphere, giving presentations at the same events, they do not explicitly 
draw from each other's work and operate in parallel: they both claim exclusive understandings of "the truth." Aficionados do not speak of other aficionados making mistakes, but instead accuse them of misleading and creating false truths. These aficionados bestow, and are tested against, moral standards of truth.

While admitting that there are distinct points of view, there is a sense that certain facts are irrefutable. Proof is required if a dispute is to be won.

Aficionados often seek verbal proof from the person, usually a musician or dancer, attributed with doing or witnessing something. Equally valid are audio and video recordings from interviews or broadcasts. However, recordings of experts making mistakes (or "telling lies") are sometimes used in accusations of incompetence and ignorance, so aficionados and academics alike must take care what they say when being recorded. The greatest onus, however, rests on writers to provide accurate information. This may account for why some aficionados prefer to speak than write books. While aficionados might be recorded, there is less likelihood of widespread condemnation than from a published script. Moreover, the written word, and books in particular, are given enormous authority by these danzón aficionados. Books are frequently consulted as sources of truths. Should they contain so-called lies, the whole of the book, and even possibly the author's entire work, will be condemned. Mizuno often expressed his disillusionment about finding inaccuracies in Yolanda Moreno Rivas' Historia de la Música Popular Mexicana (1979), co-published by an institution he holds in high esteem: Mexico's National Council for Culture and the Arts, CONACULTA. While institutions bestow experts, and in particular academics, with prestige, as well as employment and publishing opportunities, they are rarely held at fault for publishing a book containing mistakes.

Moreover, university-level educational accomplishments are often correlated with being a morally-correct and trustworthy citizen in Mexico (and beyond), and are closely allied to (racialized notions of) social class. ${ }^{4}$ All degree holders are given titles - licenciada (graduate), maestro (master or teacher), 
doctor, engineer - which are commonly used, with or without surnames, as an everyday form of address, conferring title-bearers with public prestige. Many of the lower-middle class danzón practitioners I knew were shocked when degree holders were found to be dishonest, and sometimes hinted to me, conversely, that non-degree holders were less likely to be honest. This intersected with age, as education has become increasingly accessible and numbers of degree-holders have soared. Above we saw how aficionados create the possibility of ignorance by asking stock questions. Notions of ignorance are pertinent here too, for as Hobart suggests, ignorance "is not a simple antithesis of knowledge, [but ...] is a state which people attribute to others and is laden with moral judgement" (1993:1). Ignorance is produced and moralized, Hobart argues, as "not just wrong, but as benighted and bad" (1993:21), while knowledge, and for example university education in this instance, is moralized as honest and good. Not only do (mostly middle and upper class) academics gain status from their titles and university employment, but they are also expected to be honest truth bearers. In contrast, the honesty and credibility of (the mainly lower class) investigators who are not degree holders is constantly at stake.

\section{Legitimation and Masculine Symbolic Capital}

Non-degree-holding aficionados often employ documentation as a source of personal legitimation. Activities are evidenced with letters of invitation and certificates of attendance and recognition (reconocimientos), and these adorn the walls of their homes and offices, as they do more generally in Mexico. Moreover, as is the case with academic practice, public institutional support bestows greater prestige to danzón experts and practitioners than private patronage. Mizuno gains self-satisfaction, status and prestige from invitations to speak at State Secretariats, universities, cultural centers and so forth; from travelling abroad, such as to Cuba, with expenses paid by Mexican governmental bodies; and from friendships and encounters with musicians and other people he considers erudite and important, 
such as academics and politicians. He is open about not having a degree and tells people at the beginning of his talks: "I'm not a teacher, I'm an ordinary person, like you. I'm a friend, here to try to inform you about the results of an aficionado investigator." He carried a heavy folder of papers to a conference we both attended in case he needed to prove his credentials. These included invitations to speak at cultural institutions throughout Mexico, as well as letters from CONACULTA to all the Mexican state governments ("from Aguascalientes to Zacatecas") offering his lecturing services. Yet while these letters and certificates legitimate him, and Flores y Escalante uses his books to authenticate himself, academics are validated by their titles and institutional employment and do not have to prove themselves in the same way.

In Bourdieu's terms, both academics and aficionados vie for "positiontakings" in their "fields" of expertise (1993:30). In his well-known analyses of how symbolic economies contribute to the legitimation of the dominant classes in late-twentieth-century France, Bourdieu argues that the "field of cultural production" consists of a structure, or "space of positions" in which types of capital (forms of cultural, economic, educational, and social achievement and recognition) are distributed in such a way that success may be achieved by specific positions (1993:30,60). Although fields are partly autonomous, Bourdieu argues, they are structurally homologous to each other and to the broader social world. In the French "university field," for example, Bourdieu maintains that power is acquired predominantly from "academic capital" (domination of the management and reproduction of the faculty), as opposed to "intellectual capital" (scholarly prestige) (1988:109). Cultural, educational, economic and social capital contribute to the facility with which academic and intellectual capital are obtained. The field in which aficionados struggle for positions overlaps with, but is distinct from, university fields. As García Canclini (1995) has argued, Latin American contexts lack the effective dominant classes, cultural homogeneity, or unified symbolic economy of 1970s France described by Bourdieu. Pleasure and 
emotions are notably absent from Bourdieu's notion of "field of production," and his concept of "cultural capital" (1984: 66), a cultural legitimacy gained while young, is not applicable to lower-middle class aficionados, since it must be coupled with dominant-class positions. However, there are several types of capital that Bourdieu describes which are particularly relevant to danzón aficionados. Some aficionados seek economic compensation, while others, such as Mizuno, do not. And social recognition is key, as we have seen.

Another form of capital, or prestige, that is accumulated by aficionados is a form of masculine symbolic capital. Masculine symbolic capital might be construed as essentialist tropes of hegemonic masculinity (as opposed to femininity), such as aggression and promiscuity, which can be accrued to assert a form of prestigious masculinity. Hegemonic masculinity should be read as contextual and relative, and does not preclude other manifestations of masculinity with which it might co-exist (see Gutmann, e.g., 1996, for a nuanced analysis of manhood in Mexico). Hegemonic masculinity intersects here with notions of gendered rationality-sentiment dichotomies, critiqued by feminist scholars for decades, where sentiment is allied to femininity and rationality with masculinity. As we have seen, aficionados sometimes employ fairly aggressive tactics in attempting to (re)define and demarcate the boundaries between lay and expert knowledge. And encyclopedic knowledge of truths emerges as one of the elements competed over in the accumulation of masculine symbolic capital. Furthermore, Mizuno implied to me that experts dare to speak out and say "the truth" in a country where this is far from encouraged. Both he and Flores y Escalante claimed to have had guns pulled on them (on separate occasions) for saying what they thought about danzón. Flores y Escalante told me he responded by saying that he was not an aggressive man, but had been trained in the military, and if they didn't put the pistol down "he would show them where it hurt." And ex-special policeman Mizuno countered: "if you've got the balls, shoot! But you'd better be quick, or I'll annihilate you." When telling me about this 
experience, Mizuno concluded: "people get upset when you tell them truths." Mizuno suggested to me that now that he is nearing 70, he is tired of having guns pulled on him, and no longer engages in so many conflicts over "the truth." There is a morality and a masculine symbolic capital at stake in both these aficionados' defense of "the truth" about this music-dance form. These aficionados engage with facts and positivist notions of truth with both passion and competition for masculine symbolic capital. This goes beyond a defense of their subject area, relating to a defense of greater values of truth and of rational masculinity.

Overly aggressive behavior is often frowned upon by other experts and audiences alike. Academics appear to be calmer than the majority of aficionados, and masters of ceremonies mostly keep the stakes lower. There are parallels here, however, with Jensen's (1992) analysis of fandom in the USA. Jensen has suggested that disruptive, aggressive behavior has often been associated inappropriately with fans, and "unemotional, detached, 'cool' behavior is seen as more worthy and admirable than emotional, passionate, 'hot' behavior" (1992:20). Even if danzón aficionados are sometimes aggressive, it is the way in which they express this aggression that distinguishes them from academics. Jensen continues that when juxtaposed with fans, some academics exercise a more subdued, "respectable rowdiness (acerbic asides in scholarly articles) and acceptable violence (the controlled, intellectual aggression often witnessed in conference presentations)" (1992:22). Struggles over positionings in these fields of knowledge production may be played out using similar techniques.

Another sphere in which aficionados seek to educate, moralize, and often compete for masculine symbolic capital, relates to ideas about the respectability of danzón. This manifests primarily in understandings of Mexico City’s dancehalls and cabarets, and Mexican "golden era” films, such as Julio Bracho's Distinto Amanacer (1943), Alberto Gout's Aventurera (1949), and most famously, Emilio “El Indio” Fernández’s Salón México (1948). In Salón México, for example, the protagonist, Mercedes, is a fichera (ticket-woman), a woman 
who earns money from dancing with men. Simón Jara Gámez, former Salón Colonia dancehall owner and co-author of De Cuba con Amor: El Danzón en México (1994), told me that these films confuse cabarets, where sex-workers and ficheras frequently work, with dancehalls where, he said, "prostitutes often go to have fun when they are not working" (interview, 7 June 2007, Mexico City). Like Jara Gámez assured me that dancehalls were always full of respectable people. Mizuno concurred, having frequented both dancehalls and cabarets for decades. Mizuno told me that with the danzón revival,

places where danzón was strongly scorned, criticized, banned, however you want to call it, accept it now because there was a false concept about Cuban music in general: that it was music of blacks, of slaves, and later that it was the music and dance of vulgar, common people, music of cabarets, of prostitutes etcetera (interview, 21 April 2007, Port of Veracruz).

In analyzing these ideas, it is pertinent to draw on Skeggs' (1997) work where she analyzes how in the UK, respectability is linked to "race," class, gender and sexual practices, as it is in this example and in Mexico more generally. The concern with respectability around danzón relates to notions that lower-class and racialized groups are not respectable, and, what is more, that they are polluting and dangerous. Yet instead of critiquing broader social ideas of the moral and racialized respectability of certain social classes, Jara Gámez and Mizuno mostly focused on particular individuals in defending the reputation of Mexico City's dancehalls as respectable spaces (as Moreno Figueroa 2008, has explored, discrimination is often personalized in Mexico).

However, not all aficionados agreed with them. Rather than trying to change perspectives, to make danzón respectable, Flores y Escalante celebrated the association of danzón with sex-work and lower-class groups. He told me that the "essence of danzón [...] lies with brothels and pimps, [...] with the dockers of the Port of Veracruz" (interview, 15 June 2007, Mexico City). “Danzón in Mexico 
today," he continued, is "false folklore [...] a palliative for the elderly and for people who have never had the opportunity to step into a brothel." Here, Flores y Escalante reinforces notions of danzón as essentially "deviant” and pertaining to brothels, akin to myths about tango. He exoticizes and appropriates danzón to establish his own credentials as a man who dared to enter this "dangerous" world, and who survived it with the experience required to have in-depth knowledge. However, he discussed his experiences in relation to the past, stressing that he was now happily married (and thus respectable). His lack of everyday experience in cabarets and dancehalls undermines his perspective, and the opinions of Jara Gámez and Mizuno are more representative. But what is noteworthy here is that some aficionados emphasize their personal experience of venues linked to sexwork to attain masculine symbolic capital.

Masculine symbolic capital is not available to women and most lowerclass men, who are excluded from establishing such credentials since, like women and lower class men in the UK, they have less "access to the mechanisms for generating, resisting and displaying respectability" (Skeggs 1997:2). They are less able to transcend class boundaries and claim to experience lower-class practices, or venues linked to sex-work (however inaccurately), as "other." Although a spread of Mexico's classes frequent these venues, Flores y Escalante and Mizuno are not notably distinct from other dancehall habitués in terms of identifying as lower-middle class. However, their status as aficionados contributes to enabling them to differentiate themselves from other dancehall participants. Similar processes are described in Faulk's (2000) analysis of late-nineteenth-century, English, music-hall aficionado, Arthur Symons. In his writings, Symons positions himself as an aristocratic bohemian who plays with a "tension between participation and distanced observation" (2000:175), claiming "to stand apart or above and beyond" (2000:188). However, for Faulk, it is the use of camp that, in the last instance, blurs the boundaries between professional and amateur expertise, creating a space for critical distance and theoretical reflection. Danzón 
aficionados tend not to employ camp, for another form of hegemonic masculinity is key in their struggles for symbolic capital, as are, relatedly, encyclopedic knowledge, positivist truths, and also oratory.

\section{Aficionados, Musicians, Dancers, and Academics}

Having considered how some aficionados seek to legitimate themselves, and how masculine symbolic capital contributes to the economy of their field, let us examine danzón aficionados' relationships to musicians, and to the dancers who are their primary audiences. Aficionados are mostly invited to talk at danzón festivals, rather than in dancehalls. As stated above, these festivals are often organized by powerful dance group directors, and sponsored by state institutions. Investigators - academics and aficionados - legitimate dancers' events by providing an academic element. Despite ethnomusicology being a fairly wellestablished discipline in Mexico, few academics work on danzón, so it is usually the few danzón aficionados, and sometimes musicians, who speak at the several festivals per year. The main audiences at these talks are dancers, since danzón musicians usually just turn up to play their sets. The majority of these dancers are fairly new to danzón, and aficionados regard their talks as important forums from which to transform misguided or "ignorant" ideas about danzón. Although many dancers also consider it important to have some knowledge of the history of the genre, most dancers attend danzón festivals primarily because they want to dance, rather than to learn about detailed histories. This in part explains the irritation some aficionados experienced when many dancers were not terribly interested in their truths, and the sometimes-hostile relationships between dancers and aficionados.

However, other tensions arise relating to both contexts and ways of dancing danzón. As mentioned above, since the 1980s, a more codified form of danzón dancing has emerged - danzón académico - where couples perform dozens of named, stylized steps, often in unison in groups, as a form of 
choreographed spectacle. Those aficionados who dance, mostly dance the older free-style danzón, and many disdain dancers who perform académico danzón, claiming that they are "exhibitionists." Akin to the Nicaraguan musicians discussed by Scruggs (1998) who criticized folkloricized changes to baile de marimba dancing and clothing, several danzón aficionados I encountered suggested that rather than evolving, danzón dancing was degenerating, since dancers incorporate steps from other genres such as tango (yet similar criticisms were rarely made of danzón music). Given Veracruz's renown for having excellent dancers, Mizuno asked a dancer from Veracruz: "Where are all the good dancers that Veracruz is famous for, as I can't see any?" exemplifying the sometimes-antagonistic encounters between aficionados and dancers, encounters where aficionados accuse dancers of "ignorance" or a "lack of dancing talent." Aficionados often have to prove that they can dance well in order to legitimate their statements (and Mizuno certainly does, although Flores y Escalante was more reticent). There is little doubt that learning to perform provides insights bracketed from discourse, as ethnomusicologists, dance scholars and phenomenologists have proposed. Aficionados who cannot dance are often considered unqualified to discuss danzón, although they are not expected to be musicians, as we shall see.

Paradoxically, the dancers that aficionados look down on most are the very dancers who acknowledge and bestow prestige upon them, for it is the dancers of the newer, académico style of danzón who organize and attend the festivals at which investigators speak. These dancers are the main audience of aficionados' talks (although aficionados' writings have a broader appeal). Nevertheless, the disdain and respect between dancers and aficionados is mutual. Aficionados legitimate and are legitimated by powerful dance groups (and the académico style of dancing they disdain), as well as by institutions.

In contrast to their relationship with dancers, aficionados and musicians often have a high regard for each other. Most aficionados are dancers with little 
musical training, so their understanding of danzón cannot include detailed musical analysis of danzón scores or performances (although Flores y Escalante played bugle in the military, execution of this small brass instrument, which has no valves or keys, does not require the ability to read notation or understand compositional techniques). As well as books, aficionados generally rely on musicians for their musical knowledge. Likewise, musicians often seek out aficionados for historical information about danzón. However, aficionados provide further help to musicians. For example, directors of danzoneras (danzón ensembles) consult aficionados for suggestions about repertoire or for rare recordings that they then transcribe and add to their repertoires. Scores are precious resources for musicians, and are rarely sold or exchanged. This is because in early twenty-first-century Mexico, where most danzoneras perform similar core repertoires, distinct pieces in an ensemble's repertoire can be an important marker of difference. Thus, aficionados are an important source of material for musicians. Even famous musicians acquire knowledge and recordings from aficionados, and sometimes recommendations for performances. In exchange, aficionados gain kudos from knowing (or having known) famous musicians, especially those who rarely perform in Mexico, such as the Cuban Orquesta Aragón, Cachao, Miguelito Cuní and Félix Reina (to name but four relating to Mizuno).

The majority of musicians and aficionados are men of a similar social class and, in this homosocial sphere, their relationships tend to be fairly equal (particularly those of a similar age). Moreover, musicians often work in dancehalls and cabarets, and sometimes share with aficionados years of experience of these venues. Although they occasionally vie for masculine symbolic capital, danzón aficionados and musicians mostly bestow each other with mutual prestige via mutual respect. Respect, Sennett suggests, involves being recognized by others "as a full human being whose presence matters" (2003:3). In order to engender respect, people must attain appropriate skills and abilities, 
establish their self-sufficiency, and "give back to others" (2003:63). Respect, then, emerges when it is exchanged and contextualized within social relations. While aficionados are sources of knowledge, recordings and scores for musicians, musicians often announce the presence of aficionados, dedicating pieces of music to them and bestowing them with prestige. Moreover, musicians sometimes compose danzones for money and to honor people, and Mizuno is extremely proud that Isaias Lara composed a danzón entitled Mizuno for free to honor him. ${ }^{5}$ Mizuno has given the score to several danzoneras, including Felipe Urbán y su Danzonera, La Danzonera de José Casquera and La Orquesta de Alejandro Cardona, who sometimes perform this danzón in dancehalls and at danzón events when he is present.

Yet there are instances when aficionados withhold their knowledge. While they generally disseminate their knowledge widely, aficionados are often also collectors and take pride in owning rare photographs, audio and video recordings, and interviews, refusing to copy them so they remain unique. Most of the older men who are danzón aficionados have an ambivalent relationship with technology, and few disseminate any knowledge freely via the internet. Access to information within the danzón world (and within libraries and institutions) is often released slowly and with care in Mexico, reminiscent of the way in which bureaucracy is administered more broadly, as a tool of power. However, sometimes knowledge and judgment is withheld for other reasons, for example to avoid confrontations with (powerful) others. Although I was not aware of aficionados doing this, I witnessed an experienced musician showing restraint in telling a novice musician how to improve his danzón performance. I was told by the experienced musician that he did this because he did not want to appear to wish to be better than the less-experienced musician. The dispersal of knowledge was thus suppressed. Yet restraint is sometimes juxtaposed with generosity.

Mizuno was enormously kind and generous with me, as he is with some other academics and musicians. He allowed me to study and copy part of his 
collections, including much unique and precious information such as interviews with people now deceased and rare video footage. This was a real honor, as he guards his material keenly, aware of its value as a fount from which to draw and verify information before disseminating his knowledge. It is a source conferring him prestige as an expert. Moreover, being consulted by academics and other professionals bestows him with further prestige, reconfirming his expert status (although he wanted me to clarify, when I read him this sentence, that he will not accept money for his knowledge and resources, and is less likely to share with those whose aims are economic, rather than "cultural"). As a British, UK-based academic, I have a distinct status than Mexico-based scholars. Mizuno was aware of power dynamics where white, British, middle-class academics like me appeared to have a privileged status, dynamics that I consider further in the next section. Additionally, when I met him I had very little knowledge of danzón or of Mexico, thus I became one of his protégés in a sense as my knowledge grew. Also, as a female researcher, I am less likely to vie with him for masculine symbolic capital.

In terms of methods, aficionados and academics have much in common. For example, both Mizuno and I were interested in each other's processes of acquiring and transmitting knowledge and how this knowledge was used. For Mizuno, valuable knowledge consisted of gaining "facts." Like me, he collects and studies books, documentation, recordings and memorabilia, interviews, observations and personal experiences. Mizuno interviewed me to find out where I was born (London, 1966), why I was interested in danzón (a fascinating PhD topic), and how I went about gathering information ("ethnographic fieldwork"): he added me to his collection. ${ }^{6}$ Likewise, I interviewed him asking similar questions, and storing our encounters for future reference. However, while Mizuno and I both approached our material critically and cross-referenced data, our intentions were slightly distinct. My aim drew from my British, early twentyfirst-century training in ethnomusicology, social anthropology and sociology: I 
was less interested in accumulating "facts," and more interested in trying to apprehend connections, in how truths, myths and knowledge impacted on, and legitimated, practice. Mizuno was baffled by my insistence on spending time with people he considered ignorant and giving value to their understandings of danzón. He told me: "Carry on investigating and carry on interviewing in your way, but I'm telling you that no one will tell you the truth" (interview, 12 June 2007, Mexico City). Mizuno aimed to gather, assess and disseminate "facts" and "the truth." Doing this not only gave him pleasure, but gained him respect, status, invitations to events, meetings with "important" people, a danzón named after him, and so forth. Mizuno and I valued distinct ideas about the truth, about knowledge acquisition and analysis. However, the power dynamics inherent in our epistemological outlooks remained far from equal.

As we have seen, these aficionados' relationships to musicians, and particularly dancers, include both legitimating strategies, and tensions arising from mutual respect and disdain. There are similar dynamics in interactions between danzón aficionados and academics. For example, I witnessed a wellknown Mexican historian entreating a danzón aficionado not to ask him any questions during a conference presentation, since the historian was concerned that his authority would be undermined. The aficionado obliged. He suppressed his frustration at the renowned historian's occasional errors, contributing information during question time, but refraining from publicly embarrassing the historian by pointing out inaccuracies. He later corrected the historian privately. This aficionado gains prestige from being a source for this historian, and appreciates his respect. They have a reciprocal relationship where, in the last instance, the academic historian always emerges as more prestigious and powerful: he has more "intellectual" and "academic capital" (Bourdieu 1988:109). It was clear to me that this historian invested in engaging with his peers in the academic "field," and felt less accountable to the aficionado, who he treated more as a source than as an equal. A similar occurrence played out a few weeks later with a French 
scholar and the same aficionado.

So far, I have shown how aficionados negotiate their field of expertise by employing overlapping strategies: accumulating myriad "facts" and "truths," creating the possibility of ignorance in others, and competing for hegemonic masculine capital. The ways in which aficionados package and present their knowledge (as myriad facts and singular truths) may not be fashionable in the early twenty-first-century academy, but much is lost in undervaluing their knowledge, not only because it is encyclopedic, but also in relation to their research strategies and archive creation. Greater teaching, administrative and productivity demands on academics in recent years have meant that few professional scholars have been able to amass the kind of encyclopedic knowledge aficionados often enjoy. Back proposes that increased academic specialization is creating ignorance about so many different areas that the academic can no longer assess what knowledge is important (2011:26 February entry). The academic has forsaken both detailed knowledge and general knowledge. Yet the institutional authority of the academy should never be lost sight of, for the space of recognition that aficionados might occupy is still often taken by academics, despite aficionados being important founts of knowledge for scholars. Is it now time to create mechanisms where we (regional and elite academics) can learn from the insights, blindnesses and shortcomings of distinct approaches to knowledge, and move to more egalitarian fields of expertise? Can we find ways to empower amateur knowledge producers, both economically and in terms of status?

These questions create a dilemma, however. Should we critique amateur scholars, as we might other academics, for employing forms of discrimination (such as sexism, homophobia, and racism)? In the twenty-first century, struggles over positionings in fields of expertise are still articulated in terms of intersecting contingent identities (and related discriminations), including gender, the performance of masculinity, class, ethnicity, age, nationality, sexuality, and 
language. How might we balance, on the one hand, a desire to empower and remunerate amateur researchers, and on the other, tackle sexism (which is often articulated, for example, in danzón aficionados' employment of hegemonic masculine capital, so key to their struggles for status)? This last challenge chimes with the epistemological and ethical conundrum that has overshadowed anthropology and ethnomusicology for decades: how to combine ethnographic analysis with postcolonial, feminist, and other critiques (as Strathern 1987, explores). Is it time to radically reassess how we know and what we value once again? In order to do this, relationships between academics and aficionados must be appraised within broader fields of knowledge production including regional and hegemonic scholarship. In the final section, therefore, I consider some of the power dynamics and hierarchies of knowledge that exist between regional and hegemonic scholarship more generally, concentrating primarily on academics in Latin America and the elite USA-Canada-Europe academic circuit. There are striking parallels here with the relationships discussed above between aficionados and academic experts. I draw particularly on the work of two Peruvian scholars, Javier Léon and Raúl Romero, who make incisive interventions that are significant for Mexico and many other parts of Latin America.

\section{Hierarchies of Knowledge Production, and Regional and Hegemonic Scholarship}

Léon (1999) proposes that in the first half of the twentieth century, scholars based in Peru and their counterparts in elite US, Canadian and European universities were more equal. However, in the last few decades, power imbalances have increased, as is well known. In an analysis of these power imbalances, Romero (2001) provides a comparison between Peruvian and "foreign" scholars. Peruvian scholars choose to study topics they consider politically expedient, he suggests, hoping to enact social change; they usually fall in love with their subjects of study; and are often considered by elite "others" to be "local experts," 
that is they are side-lined as insiders with insufficient critical distance to the "field" to produce authoritative research. In contrast, foreign scholars seek "intellectually interesting" themes; go through the rite of passage of (dangerous) "fieldwork;" have ultimate "ambitions of universality;" and aim to be afforded authority as "world-leading” experts (Romero 2001:53). Similar dichotomies may be constructed between Mexican and foreign scholars. Moreover, there are salient resonances here between Peruvian scholars and Mexican danzón aficionados who are interested in educating others; are enamored by their topics; and are usually less valued than (elite) academics in hierarchies of knowledge production. As a privileged, British researcher, despite attempts at circumvention, I have fallen into many of the traps of Romero's foreign scholar (some of which can be spotted in this essay).

Romero distinguishes between "hegemonic scholarship" and "regional" (Peruvian) scholarship, where hegemonic scholarship points to "an attitude and philosophy of knowledge that even Third World intellectuals can embody" (2001:55). He concedes that these are trends that the finest hegemonic and regional scholars do not fall into, but what is key here is "academic establishments as systems" (Romero 2001:59), rather than individual academics' nationalities. Romero analyzes hegemonic and regional scholarships in terms of center and periphery, applying this model internally to regional institutions and centers of academic prestige (in Peru, but also applicable within Mexico, the USA and UK), as well as more "globally." It is the elite universities of the USA, Canada and Europe from which much hegemonic scholarship emerges, for it is here that, in Bourdieusian terms, intellectual, academic and economic capital is concentrated, where disciplinary power resides, where universities have the resources to top "world" university league tables.

In relation to ethnomusicology, Léon argues that despite the diversity of approaches incorporated within hegemonic ethnomusicology, regional scholars are often relegated to subordinate positions in academic hierarchies (1999:179- 
80). For example, it is still the case that many published materials on Peru are not easily available in regional universities, but in elite libraries in the USA, Canada and Europe, thus there is a power imbalance in relation to access to sources. Moreover, as Ruiz Rodríguez (2007) points out, access to publications and recordings in Mexico relating to non-Mexican musics, for example African music, is mostly mediated by hegemonic publications such as Ethnomusicology and the Yearbook for Traditional Music. Léon (1999) continues that in addition to a broad range of published materials and possibilities of applying for large research grants, elite scholars can often easily access local Peruvian archives, where their privileged status bestows them "unspoken" benefits with local librarians. For regional (Peru-based) researchers, bureaucratic procedures and years of (sometimes nepotistic forms of) networking are required. Elite scholars mostly have access to more economic and social capital than regional academics. Similar dynamics apply to Mexican danzón aficionados who generally have less economic and social capital than Mexico-based or elite academics.

Additionally, Léon suggests, regional scholars, are less likely to engage with hegemonic ethnomusicology and anthropology, or to "fetishize" theory. As Wacquant proposes, in his discussion of the reception of Bourdieu's work amongst US social scientists,

all academic fields tend to be ethnocentric. In the case of the United States, however, this is aggravated by the 'blindness of the dominant' due to the hegemonic status of American social science worldwide. American intellectual myopia functions as the opposite of that of smaller sociologies $[\ldots]$ : while the latter cannot see themselves, the former does not see others and tends to see itself everywhere (Wacquant 1989:30).

Theory is usually grounded in the local, and the theory most fetishized by UKand US-based social scientists and ethnomusicologists tends to emanate from France (followed substantially behind by theoretical offerings from other European countries and the USA, with post-colonial scholars often emerging 
from, or educated in, these contexts). It is striking how much credence hegemonic ethnomusicologists have paid to French philosophers and social scientists - whose texts have been translated into the hegemonic language, English - while paying comparatively little attention to French ethnomusicologists. The applicability of local French (and other European and US) theories is in part due to the ideological, economic and other imperialistic flows in the past few centuries. Yet, as scholars have pointed out for decades, many of these hegemonic theories are inapplicable or require substantial revision in many contexts (e.g., Béhague 2000, called for a move away from Eurocentrism in the analysis of Latin American musics). Thus, it is unsurprising, as Léon (1999) points out, that although Peruvian researchers may be aware of hegemonic academic discourses, they may not be entranced by them. This means that scholars based outside the elite USACanada-Europe academic circuits are less likely to accrue the intellectual capital often acquired by elite scholars through the extensive use of hegemonic theory. Moreover, as Loza argues, a failure to adhere to "theoretical fetishes" can limit publishing opportunities, particularly in prestigious, elite journals (2006:362). What is more, Loza continues, the flow of theory tends to be one-way, from hegemonic to regional scholarship, with little regional theory being translated into English and taught to students in elite institutions. There are striking homologies here with relationships between academics and Mexican danzón aficionados.

Léon continues that "in off-the-record remarks," there is often an "implication that the main purpose of the Latin American scholar should be to gather data while the interpretation should be left to their American and European counterparts" (1999:180). There is a risk, Léon implies, of regional scholars being treated as junior within broader academic hierarchies, and their research as irrelevant and descriptive (1999:171). But it is not merely theoretical fetishes that distinguish regional and hegemonic scholarship, or aficionados and academics. In his analysis of US and Brazilian ecologists and their field researcher associates in eastern Amazonia, Raffles' proposes that “local knowledge" remains restricted by 
experiential, non-universality, while it is "methodology" which determines what is considered "science" (2002:331). Methodology, for Raffles, "is a process through which the hierarchies of knowledge are established, and in which the descriptive is distinguished from the analytic, the anecdotal from the systematic, the mythic from the factual, the information from the data" (2002:331).

Additionally, as Agawu propounds in Representing African Music, "institutionally sanctioned methodology leave[s] little room for contestation" (2003:xvii), so for example in ethnomusicology, fieldwork creates legitimate knowledge. In sum, in Bourdieusian terms (to fetishize this French theorist again!), both methodology (fieldwork) and theoretical "framing" (that is, universalizing) are required to attain the intellectual capital valued in hegemonic academia and to publish in journals such as this. It is very difficult for regional scholars to accrue the quantities of intellectual, academic or economic capital accessible to and valued by elite academics and their institutions given, as Léon (1999) explicates, the differential access to sufficient published materials and large research grants, the rarity with which regional scholars are invited to participate in high rank positions in the dominant US-based learned societies, and the lesser applicability of hegemonic methodology and theory to regional contexts. These imbalances are exacerbated, Romero (2001) proposes, by the way in which regional scholarship is invisibilized by elite academics: a lack of awareness of regional scholarship and developments is combined with referencing conventions which fail to distinguish between regional and elite scholars, or I might add, aficionados.

Some elite academics have attempted to address aspects of power imbalances with research interlocutors, for example by "giving voice" to research interlocutors (e.g., Strathern 1979; Vélez 2000; Watt 2004; Qureshi 2007). Others have sought to find new forms of ethnographic and historical representation (e.g., Lortat-Jacob 1995; Taylor 1998; Erlmann 1999). Stewart has argued that more space might be made for failure in new forms of ethnographic representation, rather than striving for "the perfect text in new textual solutions such as author 
positionings, formally dialogic presentations, ironic distance, and self-reflection" (1996:24). Otherwise, she warns, a new form of positivism may emerge. For Stewart, the "new ethnography" should aim to displace not just the signs or products of essentialism (generalizations, reifications) but the very desires that motivate academic essentialism itself - the desire for decontaminated 'meaning,' the need to require that visual and verbal constructs yield meaning down to their last detail, the effort to get the gist, to gather objects of analysis into an order of things (1996:26).

Like others employing feminist, postcolonial, reflexive, and deconstructive perspectives, Stewart critiques notions of scientific objectivity and knowledge hierarchies.

Yet power imbalances between regional and hegemonic actors have still to be addressed at a disciplinary level. And further work is needed to ensure that we do not merely pay lip service to realigning power. For example, as Skeggs has argued, the focus on reflexivity in recent years has to some extent failed us, since "reflexivity is a privileged disposition that reinforces entitlement rather than dedifferentiates social divisions" (2004:171). And, as Lamont (2009) explores in her ethnographic study of academic peer review processes in the USA, despite critiques of objectivity and knowledge hierarchies, (elite) academics have generally been loath to give up their status and institutional control of knowledge. While academics might encourage multiple truths and epistemologies among themselves, Lamont suggests, "in their quest for a monopoly on truth or science, social scientists and humanists often succumb to polarizing stances, arguing that there is only one correct approach to both theory and method" (2009:54). To return to amateur scholars, it is ironic, therefore, that aficionados are frequently belittled by academics for their oft relish for singular truths. Moreover, such a stance has profound implications for regional academics who may not wish to adhere to the "one correct approach to both theory and method," to fieldwork and hegemonic theoretical framing. 
Léon proposes that (and I quote him at length):

discourses regarding local scholarship continue to reveal an older subtext of evolutionism and diffusionism, a grammar of power which can, perhaps unintentionally, assign the local researcher to the academic equivalent role of the noble savage (1999:180).

He concludes that regardless of the extent to which local scholarship chooses to participate in the Western ethnomusicological discourse, local researchers should not be viewed as segmented Others to which overtures of respect and recognition are made from a distance. Indeed, Western academia should begin to consider how the voice of the local scholar can allow the West to engage in a more reflexive and deconstructive discourse about itself (1999:180).

While individual academics and their institutions are still valued in terms of intellectual, academic, and economic capital, hierarchies of knowledge will remain. Moreover criticism alone is not enough, for as Léon points out: where the default is to criticize the West and to celebrate the rest because the opposite would be ethnocentric, the local scholar continues to be reified into a symbol with which the West seeks to reinvent itself and thus exercise its legacy of colonialism (1999:178).

In addition to Léon's call for reflexivity and criticism, collective activism is required to reconfigure value systems and symbolic economies, and to fight institutional pressures to reproduce existing power structures. As Loza entreats: "we owe it to ourselves and to our students to work towards a closer global unity in intellectual thought and ideological action" (2006:368). However, Santamaría Delgado (2007) suggests, criticism, and I would add collective action, must come from both regional and elite institutions, from more and less privileged actors. She asks why music classified as "folkloric" and "popular" was excluded from Colombian music academies, and critiques those academies that adhered to French conservatoire models and distinguished between "art" and "artisan" music, 
thereby excluding musics including the "national" bambuco (Santamaría Delgado 2007:8-9). Likewise, Ochoa Gautier (2006) has explored how the mostly-amateur scholars of Colombian folkloric and popular musics were excluded from the academy, including folklorists, composers, performers, journalists, and literati. Greater numbers of Latin American academies are including ethnomusicology and popular music studies into their curricula, and for example, danzón aficionados are increasingly being approached by postgraduate students researching theses, and being asked to lecture in universities (for honorarium). However, even where these disciplines are incorporated into regional academies, there is still much work to be done to level the playing field and reconfigure hierarchies of knowledge and power. Elite academics must collaborate further to enact change, for, as Romero explicates, beyond "personal ambitions," elite scholars are under

pressures, which drive individual writers to play by the rules if they want to achieve academic success. Field research has to be 'innovative,' data must be fresh, related literature must be recent and accessible, and secondary sources must be of secondary importance within the research and the final report. Those who comply with such requirements are attributed with ethnographic 'authority,' which for many years, perhaps for a lifetime, will allow the scholar to enjoy the benefits of a permanent and secure position in the 'center' of the intellectual work (2001:54).

But the onus is on all of us, elite, regional scholars and aficionados, to act collectively to understand and change the workings of these fields; to endeavor not to perpetuate the value systems of these hierarchies of knowledge production; and to recognize how academic, intellectual and economic capital play in to reproducing power and authority. 


\section{Acknowledgments}

I would like to thank Ciro Carlos Mizuno Gúzman, Jesús Flores y Escalante, Mónica Moreno Figueroa, Henry Stobart, David Lehmann, James Butterworth, Rebecca Ellis, Les Back, Peter Wade, the anonymous reviewers, Ellen Koskoff, and conferees at the Foro Universitario de Etnomusicología, Xalapa, Mexico, University of London Latin American Music Seminar, and British Forum of Ethnomusicology and Latin American Studies Association conferences for their help with this paper. Funding for this research was generously provided by the UK Arts \& Humanities Research Council.

\section{Notes}

${ }^{1}$ All translations are my own unless otherwise stated.

${ }^{2}$ Canonic danzón repertoire performed in Mexico in the first decades of the twenty-first century includes Amador Dimas Pérez Torres’ Nereidas, Abelardo Valdés' Almendra, Gilberto Guzmán Concha’s Cecilia, Coralia López's Isora Club, Mozart's La Flauta Mágica arranged by Antonio María Romeu with Alfredo Brito, Silvio Contreras Fernández's Masacre, Leopoldo Olivares’ Mi Consuelo es Amarte, Emilio Renté's Mocambo, Gustavo Moreno's Pulque para Dos, Aniceto Díaz's Teléfono de Larga Distancia.

${ }^{3}$ In the early twenty-first century, danzoneras often incorporated clarinets, saxophones, trumpets, trombone, timbales, güiro, keyboard and bass. Well-known danzoneras in Mexico City included Danzonera de Acerina and Danzonera Dimas, and in Veracruz, Alma de Veracruz and Danzonera La Playa.

${ }^{4}$ While I do not discuss the racialized implications of knowledge production here, I explore the relationship of racialization processes and danzón elsewhere (2010a). 
This is a preprint of an article by Hettie Malcomson published in Ethnomusicology (2014), available online at: http://www.jstor.org/stable/10.5406/ethnomusicology.58.2.0222

5 The montuno section of Isaias Lara's danzón Mizuno includes an arrangement of Richard Egües' El Trago. I am grateful to Sue Miller for alerting me to this. Mizuno told me that he requested permission from Richard Egües for the inclusion of these four bars in this danzón.

${ }^{6}$ I lived in the Port of Veracruz from 2006-2008, returning annually since (with contextual visits to Cuba and Mexico City). 
This is a preprint of an article by Hettie Malcomson published in Ethnomusicology (2014), available online at: http://www.jstor.org/stable/10.5406/ethnomusicology.58.2.0222

\section{References}

Agawu, Kofi V. 2003. Representing African Music: Postcolonial Notes, Queries, Positions. New York and London: Routledge.

Back, Les. 2011. Academic Diary. http://www.academic-diary.co.uk.

Barz, Gregory F., and Timothy J. Cooley, eds. 1997. Shadows in the Field: New Perspectives for Fieldwork in Ethnomusicology. New York and Oxford: Oxford University Press.

Basso, Keith H. 1996. Wisdom Sits in Places: Landscape and Language among the Western Apache. Albuquerque: University of New Mexico Press.

Béhague, Gerard. 2000 "Boundaries and Borders in the Study of Music in Latin America: A Conceptual Re-Mapping." Latin American Music Review/Revista de Música Latinoamericana 21(1):16-30.

Bourdieu, Pierre. 1984. Distinction: A Social Critique of the Judgement of Taste, translated by Richard Nice. New York, London: Routledge. 1988. Homo Academicus, translated by Peter Collier. Cambridge: Polity Press. 1993. The Field of Cultural Production: Essays on Art and Literature, translated by Richard Nice, edited by Randal Johnson. Cambridge: Polity.

Camp, Roderic A., Charles A. Hale, and Josefina Zoraida Vázquez, eds. 1991. Los Intelectuales y el Poder en México. México D.F.: El Colegio de México, University of California Los Angeles.

Carpentier, Alejo. 1946. La Música en Cuba. 2nd ed. México D.F.: Fondo de Cultura Economica.

Clifford, James. 1986. "Introduction: Partial Truths." In Writing Culture: The Poetics and Politics of Ethnography, edited by James Clifford and George E. Marcus, 1-26. Berkeley: University of California Press.

Dueñas Herrera, Pablo. 1993. Bolero: Historia Documental del Bolero Mexicano. México D.F.: Asociación Mexicana de Estudios Fonográficos.

Erlmann, Veit. 1999. Music, Modernity, and the Global Imagination: South Africa and the West. New York: Oxford University Press.

Faulk, Barry J. 2000 "Camp Expertise: Arthur Symons, Music-Hall, and the Defense of Theory." Victorian Literature and Culture:171-93.

Fiske, John. 1992. "The Cultural Economy of Fandom." In The Adoring Audience: Fan Culture and Popular Media, edited by Lisa A. Lewis, 3049. London: Routledge.

Flores y Escalante, Jesús. 1993. Salón México: Historia Documental y Gráfica del Danzón en México. 2 ed. México D.F.: Asociación Mexicana de Estudios Fonográficos. 1994a. Brevísima Historia de la Comida Mexicana. 2 ed. México D.F.: Asociación Mexicana de Estudios Fonográficos. 1994b. Imagenes del Danzón: Iconografia del Danzón en México. 2 ed. México D.F.: Asociación Mexicana de Estudios Fonográficos. 1994c. Morralla del Caló Mexicano. 2 ed. México D.F.: Asociación Mexicana de Estudios Fonográficos. 
This is a preprint of an article by Hettie Malcomson published in Ethnomusicology (2014), available online at: http://www.jstor.org/stable/10.5406/ethnomusicology.58.2.0222

Galán, Natalio. 1983. Cuba y sus Sones. Madrid: Pre-Textos.

García Canclini, Néstor. 1995. Hybrid Cultures: Strategies for Entering and Leaving Modernity, translated by Silvia L. López and Christopher L. Chiappari. Minneapolis, MN: University of Minnesota Press.

García de León Griego, Antonio. 1996. "Con la Vida de un Danzón: Notas sobre el Movimiento Inquilinario de Veracruz en 1922." In Actores Sociales en un Proceso de Transformación: Veracruz en los Años Veinte, edited by Manuel Reyna Muñoz, 33-53. Xalapa: Universidad Veracruzana.

García Díaz, Bernardo. 2002. "Danzón y Son: Desde Cuba a Veracruz (18801930).” In México y el Caribe: Vínculos, Intereses, Region, edited by Laura Muñoz, 266-81. México D.F.: Instituto Mora.

Gramsci, Antonio. 2011. "Notebook 4 (1930-1932)." In Prison Notebooks, Volume II, 135-264. New York: Columbia University Press.

Grossberg, Lawrence. 1992. "Is There a Fan in the House?: The Affective Sensibility of Fandom.” In The Adoring Audience: Fan Culture and Popular Media, edited by Lisa A. Lewis, 50-65. London: Routledge.

Gutmann, Matthew C. 1996. The Meanings of Macho: Being a Man in Mexico City. Berkeley, Los Angeles and London: University of California Press.

Haraway, Donna J. 1988 "Situated Knowledges: The Science Question in Feminism and the Privilege of Partial Perspective." Feminist Studies 14(3):575-99.

Harding, Sandra. 1996. "Rethinking Standpoint Epistemology: What Is 'Strong Objectivity'?" In Feminism and Science, edited by Evelyn Fox Keller and Helen E. Longino. New York: Oxford University Press.

Hills, Matt. 2002. Fan Cultures. London and New York: Routledge.

Hobart, Mark. 1993. "Introduction: The Growth of Ignorance?" In An Anthropological Critique of Development: The Growth of Ignorance, edited by Mark Hobart, 1-30. London and New York: Routledge.

Hood, Mantle. 1960 “The Challenge of 'Bi-Musicality'.” Ethnomusicology 4:5559.

Jenson, Joli. 1992. "Fandom as Pathology: The Consequences of Characterization." In The Adoring Audience: Fan Culture and Popular Media, edited by Lisa A. Lewis, 9-29. London: Routledge.

Kurzman, Charles, and Lynn Owens. 2002 "The Sociology of Intellectuals." Annual Review of Sociology 28:63-90.

Lamont, Michèle. 2009. How Professors Think: Inside the Curious World of Academic Judgment. Boston: Harvard.

León, Argeliers. 1984. Del Canto y el Tiempo. La Habana: Editorial Letras Cubanas.

Léon, Javier F. 1999 "Peruvian Musical Scholarship and the Construction of an Academic Other.” Latin American Music Review/Revista de Música Latinoamericana 20(2):168-83.

Lewis, Lisa A., ed. 1992. The Adoring Audience: Fan Culture and Popular Media. London: Routledge. 
This is a preprint of an article by Hettie Malcomson published in Ethnomusicology (2014), available online at: http://www.jstor.org/stable/10.5406/ethnomusicology.58.2.0222

Lortat-Jacob, Bernard. 1995. Sardinian Chronicles. Chicago: University of Chicago Press.

Loza, Steven. 2006 "Challenges to the Euroamericentric Ethnomusicological Canon: Alternatives for Graduate Readings, Theory, and Method." Ethnomusicology 50(2):360-71.

Malcomson, Hettie. 2010a. "La Configuración Racial del Danzón: Los Imaginarios Raciales del Puerto de Veracruz." In Mestizaje, Diferencia y Nación, edited by Elisabeth Cunin, 267-98. México D.F.: INAH, UNAM, CEMCA, IRD.

" "Creative Standardization: Danzón and the Port of Veracruz, Mexico." $\mathrm{PhD}$ Thesis, University of Cambridge, 2010b.

2011 "The 'Routes' and 'Roots' of Danzón: A Critique of the History of a Genre.” Popular Music 30(2):263-78.

2012 "New Generations, Older Bodies: Danzón, Age and 'Cultural

Rescue' in the Port of Veracruz, Mexico.” Popular Music 31(2):217-30.

Mol, Annemarie. 2003. The Body Multiple: Ontology in Medical Practice.

Durham, NC and London: Duke University Press.

Monsiváis, Carlos. 1981. Escenas de Pudor y Liviandad. México D.F.: Grijalbo.

Moreno Figueroa, Mónica G. 2008 "Historically Rooted Transnationalism:

Slightedness and the Experience of Racism in Mexican Families." Journal of Intercultural Studies 29(3):283-97.

Moreno Rivas, Yolanda. 1979. Historia de la Música Popular Mexicana. México

D.F.: Editorial Patria.

Ochoa Gautier, Ana María. 2006 "Sonic Transculturation, Epistemologies of Purification and the Aural Public Sphere in Latin America." Social Identities 12(6):803-25.

Pedwell, Carolyn, and Anne Whitehead. 2012 “Affecting Feminism: Questions of Feeling in Feminist Theory." Feminist Theory 13(2):115-29.

Piedras Feria, Ernesto. 2006. "Crecimiento y Desarollo Económicos Basados en la Cultura." In Las Industrias Culturales y el Desarollo de México, edited by Néstor García Canclini and Ernesto Piedras Feria, 45-86. México D.F.: Siglo XXI Editores.

Qureshi, Regula. 2007. Master Musicians of India: Hereditary Sarangi Players Speak. London and New York: Routledge.

Raffles, Hugh. 2002 “Intimate Knowledge.” International Social Science Journal 54(3):325-35.

Romero, Raúl R. 2001 "Tragedies and Celebrations: Imagining Foreign and Local Scholarships.” Latin American Music Review/Revista de Música Latinoamericana 22(1):48-62.

Ruiz Rodríguez, Carlos. 2007 "Estudios en Torno a la Influencia Africana en la Música Tradicional de México: Vertientes, Balance y Propuestas." Revista Transcultural de Música, Transcultural Music Review 11.

Santamaría Delgado, Carolina. 2007 "El Bambuco, los Saberes Mestizos y la Academia: Un Análisis Histórico de la Persistencia de la Colonialidad en 
los Estudios Musicales Latinoamericanos." Latin American Music Review/Revista de Música Latinoamericana 28(1):1-23.

Scruggs, T.M. 1998 "Cultural Capital, Appropriate Transformations, and Transfer by Appropriation in Western Nicaragua: 'El Baile de la Marimba'." Latin American Music Review/Revista de Música Latinoamericana 19(1):1-30.

Seeger, Charles. 1949 "Professionalism and Amateurism in the Study of Folk Music." The Journal of American Folklore 62(244):107-13. Translated into Spanish: "El professional y el aficionado en el estudio de la música folklórica," Revista Musical Chilena (1959) 16(68): 70-79.

Sennett, Richard. 2003. Respect: The Formation of Character in a World of Inequality. London: Allen Lane, Penguin Books.

Sevilla, Amparo. 2003. Los Templos del Buen Bailar. México D.F.: Consejo Nacional para la Cultura y las Artes.

Skeggs, Beverley. 1997. Formations of Class and Gender: Becoming Respectable. London: Sage.

- 2004. Class, Self, Culture. London and New York: Routledge.

Stewart, Kathleen. 1996. A Space on the Side of the Road: Cultural Poetics in an "Other" America. Princeton, NJ: Princeton University Press.

Strathern, Andrew. 1979. Ongka: A Self-Account by a New Guinea Big-Man. New York: St. Martin's Press.

Strathern, Marilyn. 1987 "An Awkward Relationship: The Case of Feminism and Anthropology." Signs 12(2):276-92.

Taylor, Julie. 1998. Paper Tangos. Durham, NC and London: Duke University Press.

Trejo, Ángel. 1992. Hey, Familia, Danzón Dedicado a ...! México D.F.: Plaza y Valdés.

Turino, Thomas. 2003 "Nationalism and Latin American Music: Selected Case Studies and Theoretical Considerations." Latin American Music Review/Revista de Música Latinoamericana 24(2):169-209.

Vélez, María Teresa. 2000. Drumming for the Gods. The Life and Times of Felipe García Villamil, Santero, Palero, and Abakuá. Philadelphia: Temple University Press.

Viveiros de Castro, Eduardo. 1998 "Cosmological Deixis and Amerindian Perspectivism." The Journal of the Royal Anthropological Institute 4(3):469-88.

Wacquant, Loïc J. D. 1989 “Towards a Reflexive Sociology: A Workshop with Pierre Bourdieu." Sociological Theory 7.

Watt, Eva Tulene, with Basso, Keith H. 2004. Don't Let the Sun Step over You: A White Mountain Apache Family Life, 1860-1975. Tucson: University of Arizona Press.

Williams, Raymond. 1983. Keywords: a Vocabulary of Culture and Society (Revised Edition). London: Fontana. 
This is a preprint of an article by Hettie Malcomson published in Ethnomusicology (2014), available online at: http://www.jstor.org/stable/10.5406/ethnomusicology.58.2.0222

\section{Discography}

Danzones del Porfiriato y la Revolución. 1994. México D.F.: Asociación Mexicana de Estudios Fonográficos AMEF CD 4403. Compact disc.

Un Siglo de Cantantes en el Cine Mexicano. 2001. México D.F.: Asociación Mexicana de Estudios Fonográficos AMEF CD 4407. Compact disc.

\section{Filmography}

Bracho, Julio. 1943. Distinto Amanacer. México D.F.: Films Mundiales. 108 minutes. Fernández, Emilio. 1948. Salón México. México D.F.: CLASA Films Mundiales. 90 minutes.

Gout, Alberto. 1949. Aventurera. México D.F.: Producciones Calderón. 101 minutes. Novaro, María. 1991. Danzón. México D.F.: IMCINE. 120 minutes. 